\title{
Distribution of inhaled fluticasone propionate between human lung tissue and serum in vivo
}

\author{
N. Esmailpour*, P. Högger*, K.F. Rabe**, U. Heitmann**, \\ M. Nakashima**, P. Rohdewald*
}

Distribution of inhaled fluticasone propionate between human lung tissue and serum in vivo. N. Esmailpour, P. Högger, K.F. Rabe, U. Heitmann, M. Nakashima, P. Rohdewald. C CERS Journals Ltd 1997.

ABSTRACT: High retention of inhaled glucocorticoids in the airways means prolonged anti-inflammatory action and low delivery into the serum. The objective of this study was to investigate the retention in and distribution of inhaled fluticasone propionate (FP) between central and peripheral human lung tissue and serum in vivo.

In 17 patients undergoing lung resection surgery, a single $1.0 \mathrm{mg}$ dose of FP was inhaled at varying time-points (range $2.8-21.7 \mathrm{~h}$ ) preoperatively. Peripheral and central lung tissue was obtained, and blood was drawn simultaneously.

FP concentrations in central lung tissue were approximately three to four times higher than peripheral lung tissue concentrations, which in turn, exceeded those found in serum by 10 times. FP was detectable up to 21 and $16 \mathrm{~h}$, respectively, after inhalation, with drug levels falling almost in parallel in peripheral lung tissue and in serum.

The results of this study demonstrate that fluticasone propionate is retained in lung tissue for a long time. Serum concentrations after a single inhaled dose are low. Retention of high concentrations of fluticasone propionate in the airways may promote high topical anti-inflammatory activity.

Eur Respir J 1997; 10: 1496-1499.
*Institut für Pharmazeutische Chemie, Westfälische Wilhelms-Universität Münster, Münster, Germany. **Krankenhaus Großhansdorf, Zentrum für Pneumologie und Thoraxchirurgie, LVA Hamburg, Germany.

Correspondence: P. Rohdewald

Institut für Pharmazeutische Chemie

Westfälische Wilhelms-Universität 48149 Münster

Germany

Keywords: Fluticasone propionate glucocorticoid inhalation

plasma concentration

tissue concentration in vivo

Received: July 301996

Accepted after revision April 201997

The investigation was supported by GlaxoWellcome.
The ideal corticosteroid for use by inhalation in the treatment of asthma should act effectively in the airways and produce a minimum of systemic effects within its dose range [1]. To achieve this, the compound should have a high intrinsic topical activity (anti-inflammatory potency) combined with low oral systemic bioavailability [2]. It is favourable for a corticosteroid to display high retention in the airways and low delivery into plasma after inhalation. Therefore, it is of interest to investigate the distribution of glucocorticoids between lung tissue and blood.

Potent glucocorticoids have a high affinity for the glucocorticoid receptor. Of all corticosteroids tested, fluticasone propionate (FP) has the highest in vitro affinity for the glucocorticoid receptor in human lung [3, 4]. Binding and retention studies in human lung in vitro have demonstrated high tissue concentrations for FP (similar to beclomethasone dipropionate and its active metabolite, but greater than budesonide, flunisolide and hydrocortisone), compared with blood plasma concentrations [5-7].

To demonstrate the clinical relevance of these data, we present the first investigation of the tissue-plasma distribution of FP in humans. In this study, the distribution of a single $1.0 \mathrm{mg}$ dose of FP between human lung tissue and blood plasma was studied in vivo.
Materials and methods

\section{Patients and study design}

The study was approved by the local Ethics Committee. Informed consent to participate in the study was obtained from 17 patients (16 males and 1 female) with bronchial carcinoma, who were referred for pneumectomy or lobe resection. Their mean $( \pm \mathrm{SD})$ age was $58 \pm 6$ yrs (range 48-67 yrs). Squamous cell carcinomas were found in 11 patients, five patients had adenocarcinoma, and one patient had a carcinoid tumour. Vital capacity ranged 2.7-6.1 L, and forced expiratory volume in one second (FEV1) $58-115 \%$ of predicted (table 1).

At varying times before surgery (range 2.8-21.6 h), $1.0 \mathrm{mg}$ FP was administered via a large volume spacer, Volumatic $^{\mathrm{TM}}$ (four puffs each of $250 \mu \mathrm{g}$ ), and the time of administration was recorded. Thirty to $45 \mathrm{~min}$ before intubation, $0.5 \mathrm{mg}$ atropine sulphate and an analgesic were given to patients as premedication. Peripheral and central lung tissue free of tumour was obtained for analysis of FP. A blood sample was drawn intraoperatively at the time-point of ligation of the pulmonary artery for analysis. Whole blood was centrifuged and serum samples were frozen and stored until analysed at $-20^{\circ} \mathrm{C}$. The time after inhalation, identical with time 
Table 1. - Patient characteristics, lung function parameters and medical data

\begin{tabular}{|c|c|c|c|c|c|c|c|c|c|}
\hline $\begin{array}{l}\mathrm{Pt} \\
\text { No. }\end{array}$ & $\begin{array}{l}\text { Age } \\
\text { yrs }\end{array}$ & Sex & $\begin{array}{l}\text { Smoking } \\
\text { status }\end{array}$ & $\begin{array}{l}\text { Type of } \\
\text { operation }\end{array}$ & Histology & $\begin{array}{c}\mathrm{VC} \\
\mathrm{L}\end{array}$ & $\begin{array}{l}\text { FEV } 1 \\
\% \text { pred }\end{array}$ & $\begin{array}{l}\text { Time between } \\
\text { inhalation and } \\
\text { resection } h\end{array}$ & Comments \\
\hline 1 & 60 & M & Smoker & $\mathrm{PN}$ & $\mathrm{AC}$ & 3.6 & 80 & 4.7 & - \\
\hline 2 & 61 & M & Smoker & PN & $\mathrm{AC}$ & 3.8 & 80 & 3.7 & - \\
\hline 3 & 67 & M & Ex & PN & $\mathrm{AC}$ & 3.3 & 79 & 2.8 & - \\
\hline 4 & 50 & $\mathrm{~F}$ & Smoker & LR & Carcinoid & 2.7 & 61 & 14.0 & Plasma only \\
\hline 5 & 51 & M & $\mathrm{Ex}$ & PN & $\mathrm{SC}$ & 5.2 & 104 & 3.3 & - \\
\hline 6 & 59 & M & Ex & PN & $\mathrm{SC}$ & 4.7 & 94 & 12.3 & - \\
\hline 7 & 61 & M & Smoker & LR & $\mathrm{AC}$ & 4.1 & 87 & 3.7 & - \\
\hline 8 & 62 & M & Smoker & PN & $\mathrm{SC}$ & 4.4 & 93 & 12.7 & Viscous mucus \\
\hline 9 & 60 & M & Smoker & PN & SC & 6.1 & 105 & 13.3 & - \\
\hline 10 & 57 & M & Smoker & PN & SC & 3.2 & 58 & 17.5 & - \\
\hline 11 & 50 & M & Smoker & PN & $\mathrm{SC}$ & 4.1 & 101 & 11.1 & Viscous mucus \\
\hline 12 & 56 & M & Ex & $\mathrm{PN}$ & $\mathrm{SC}$ & 5.6 & 98 & 12.1 & Viscous mucus \\
\hline 13 & 64 & M & Ex & $\mathrm{PN}$ & $\mathrm{SC}$ & 5.5 & 115 & 21.2 & - \\
\hline 14 & 51 & M & Smoker & PN & $\mathrm{AC}$ & 4.2 & 70 & 16.3 & - \\
\hline 15 & 58 & M & Smoker & PN & $\mathrm{SC}$ & 5.1 & 83 & 17.2 & - \\
\hline 16 & 48 & M & Smoker & PN & $\mathrm{SC}$ & 3.5 & 67 & 13.3 & - \\
\hline 17 & 66 & M & Smoker & PN & $\mathrm{SC}$ & 4.1 & 68 & 16.9 & - \\
\hline
\end{tabular}

Pt: patient; M: male; F: female; Ex: ex-smoker; PN: pneumonectomy; LR: lobe resection; AC: adenocarcinoma; SC: squamous cell carcinoma; VC: vital capacity; FEV1: forced expiratory volume in one second; \% pred: percentage of predicted value. FEV1 $\%$ pred for males: $\mathrm{FEV}_{1} /(4.3 \times($ height/100)) $-(0.029 \times$ age $)-2.49) \times 100$. FEV1 \% pred for females: FEV1/(3.95 × (height/100))$(0.025 \times$ age $)-2.6) \times 100$.

between inhalation and resection, has been defined as the time between inhalation and the ligation of the pulmonary artery.

\section{Materials}

Chemicals were purchased from Sigma (Deisenhofen, Germany) or Merck (Darmstadt, Germany), activated charcoal Norit Gsx was from BDH (Wesel, Germany). Fluticasone-17-propionate (FP), tritiated FP (specific activity $\left.55.4 \mathrm{Ci} \cdot \mathrm{mmol}^{-1}\right)$ and $\mathrm{FP}$ antiserum [8] were a generous gift from Glaxo Wellcome (Greenford, UK). Solid phase extraction cartridges, $\mathrm{C}_{18}$-SPE-columns, were obtained from J.T. Baker (Philipsburg, USA), scintillation cocktail Aquasafe 500 Plus and $4 \mathrm{~mL}$ polyethylene vials were from Zinsser (Frankfurt, Germany), and $2 \mathrm{~mL}$ incubation tubes were obtained from Eppendorf (Hamburg, Germany).

Assay buffer $\left(\mathrm{pH} 7.4\right.$ at $\left.4^{\circ} \mathrm{C}\right)$ consisted of $100 \mathrm{mM}$ tricine, $150 \mathrm{mM}$ sodium chloride, and $15 \mathrm{mM}$ sodium azide. Tricine-ethanol buffer contained $5 \%(\mathrm{v} / \mathrm{v})$ ethanol in assay buffer, and tricine-gelatine buffer contained $0.1 \%$ gelatine $(\mathrm{w} / \mathrm{v})$ in assay buffer. Dextran-coated charcoal suspension consisted of $0.5 \%(\mathrm{w} / \mathrm{v})$ Norit Gsx and $0.05 \%(\mathrm{w} / \mathrm{v})$ dextran. The working dilution of $\left[{ }^{3} \mathrm{H}\right]-\mathrm{FP}$ was $532.4 \mathrm{pmol} \cdot \mathrm{L}^{-1}$, and the working solution of FP antiserum resulted in $50 \%$ binding of $\left[{ }^{3} \mathrm{H}\right]-\mathrm{FP}$.

\section{Quantification of FP in lung tissue}

Tissue was pulverized and one part tissue was homogenized (Ultra-turrax, Jahnke Kunkel, Germany; Potter S, Braun Melsungen, Germany) with three parts of assay buffer. An aliquot $(2.0 \mathrm{~g})$ of the tissue suspension was frozen in liquid nitrogen and lyophilized. The pellet was extracted twice with $5.0 \mathrm{~mL}$ methanol, and an aliquot of the extract was evaporated at $50^{\circ} \mathrm{C}$ under a gentle nitrogen flow. Dry extracts were reconstituted in $0.1 \mathrm{~mL}$ tricine-ethanol buffer and $0.1 \mathrm{~mL}$ tricine-gelatine buffer. Samples were mixed with $0.1 \mathrm{~mL}$ of FP antiserum solution and incubated at $0^{\circ} \mathrm{C}$ for $30 \mathrm{~min}$. For determination of nonspecific binding, antiserum solution was replaced by assay buffer. After $30 \mathrm{~min}, 0.1 \mathrm{~mL}$ of $\left[{ }^{3} \mathrm{H}\right]-\mathrm{FP}$ was added and incubation was continued for another $30 \mathrm{~min}$ at $0^{\circ} \mathrm{C}$. The reaction was stopped by addition of $1.0 \mathrm{~mL}$ dextran-coated charcoal suspension. Samples were incubated for $10 \mathrm{~min}$ on ice and centrifuged. A $1.0 \mathrm{~mL}$ aliquot of the supernatant was counted for radioactivity. Mean $( \pm S D)$ recovery was $90 \pm 3 \%(n=8)$ for tissue samples. Calibration curves were prepared with blank tissue (swine lungs). Specific binding was $75 \pm 4 \%$ for human lung tissue $(n=8)$ and $80 \pm 2 \%$ for swine tissue $(n=8)$. Thus, specific binding was not statistically significantly different between human and swine lung tissue. There was no detectable difference in calibration curves obtained with swine tissue compared to calibration curves obtained with blank human lung tissue. Curves were linear, the coefficient of correlation was $r=0.99 \pm 0.01 \quad(n=5)$. The lower limit of quantification was $1 \mathrm{pg} \cdot \mathrm{mg}^{-1}$.

\section{Quantification of FP in serum}

Frozen serum samples were thawed. Solid phase extraction cartridges were equilibrated with $1 \mathrm{~mL}$ methanol, and subsequently with $1 \mathrm{~mL}$ assay buffer. A $1.0 \mathrm{~mL}$ aliquot of serum samples was applied to the column. The cartridges were washed with $1 \mathrm{~mL}$ assay buffer and $1 \mathrm{~mL}$ distilled water, and dried for 2 min under vacuum. FP was eluted with $1.0 \mathrm{~mL}$ methanol, and the eluate was evaporated at $50^{\circ} \mathrm{C}$ under a gentle nitrogen flow. Radioimmunoassay (RIA) was performed as described for tissue samples. Recovery was $95 \pm 0.8 \%(n=8)$ for serum samples. Calibration curves were prepared with blank human serum. Curves were linear and the coefficient of correlation was $r=0.99 \pm 0.01 \quad(n=6)$. The lower limit of quantification was $25 \mathrm{pg} \cdot \mathrm{mL}^{-1}$. 


\section{Results}

FP concentrations of $0-6 \mathrm{ng} \cdot \mathrm{g}^{-1}\left(0-12 \mathrm{nmol} \cdot \mathrm{kg}^{-1}\right)$ found in peripheral lung tissue, were approximately 100 times greater than the FP concentrations of $0-0.11 \mathrm{ng} \cdot \mathrm{mL}^{-1}$ $\left(0-0.22 \mathrm{nmol} \cdot \mathrm{L}^{-1}\right)$ in serum, (figs. 1 and 2). Levels of FP in peripheral lung and serum fell almost in parallel with time after inhalation. Regression analysis of the two sets of data revealed high coefficients of correlation between concentration and time: $r=0.70, p<0.01$; and $\mathrm{r}=0.79, \mathrm{p}<0.01$, respectively.

The serum concentration of FP was generally below $0.1 \mathrm{ng} \cdot \mathrm{mL}^{-1}$, with the exception of one data point contributed by a patient with viscous airway mucus (this outlier was not used for regression analysis). Peripheral lung tissue concentrations of FP could be detected up to $16.3 \mathrm{~h}$, and serum concentrations up to $13.3 \mathrm{~h}$ after inhalation. Concentrations of FP were generally higher (by three to four times) in central tissue, compared with concentrations in peripheral lung tissue (fig. 1), although

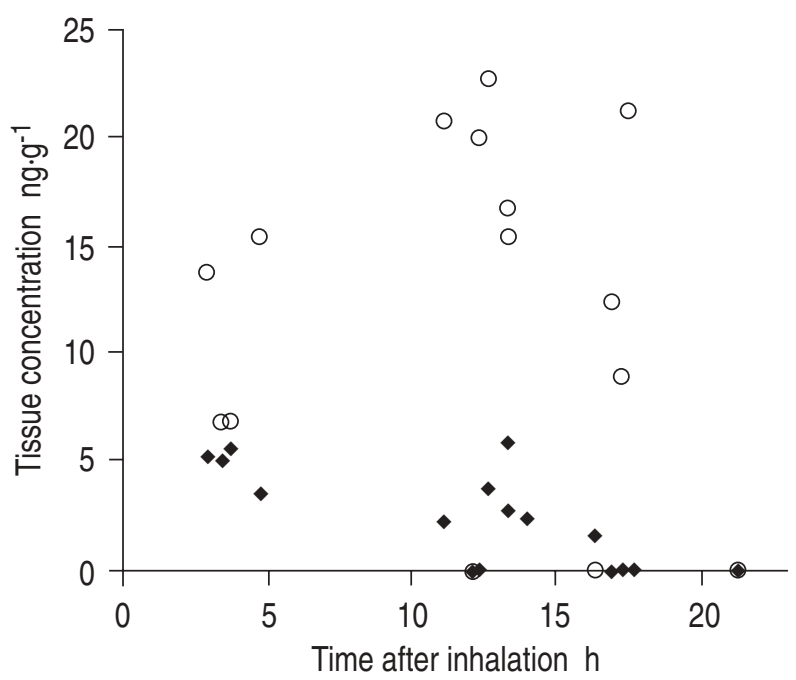

Fig. 1. - Concentration of fluticasone propionate (FP) in central and peripheral lung tissue after inhalation of $1 \mathrm{mg}$. Symbols represent single patient data. $\bigcirc$ : FP concentration in central lung tissue; $\bullet$ : FP concentration in peripheral lung tissue

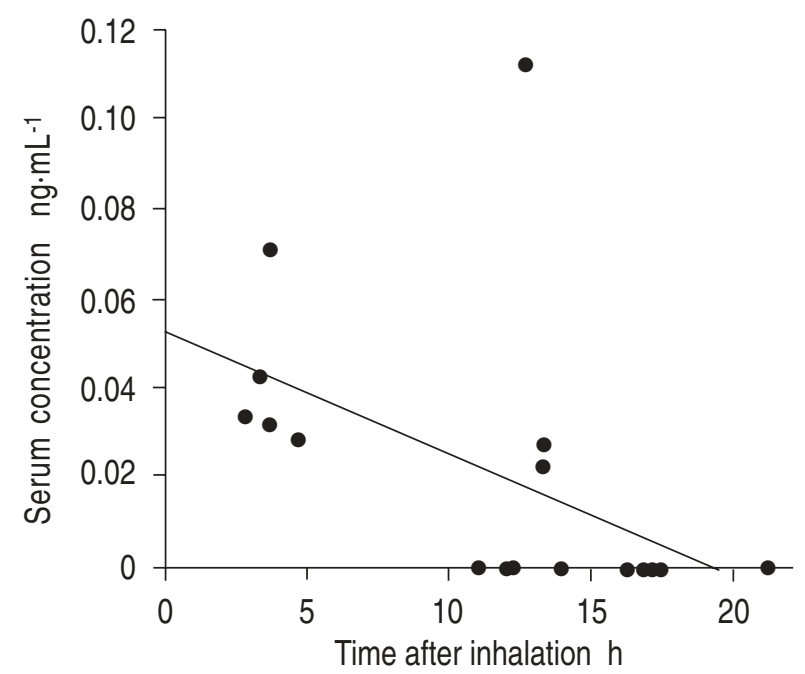

Fig. 2. - Concentration of fluticasone propionate (FP) in human serum after inhalation of $1 \mathrm{mg}$. Symbols represent single patient data. - FP concentration in serum. interindividual variation in central lung tissue drug concentrations was high (range $<1 \mathrm{ng} \cdot \mathrm{g}^{-1}$ to $23 \mathrm{ng} \cdot \mathrm{g}^{-1}$ ). Concentrations of FP in central lung tissue persisted at a high level up to $17 \mathrm{~h}$, with the exception of one patient.

\section{Discussion}

This study showed that FP concentrations in central lung tissue were about three to four times higher than in peripheral lung tissue, which in turn exceeded those found in serum by 100 times. No relevant information can be drawn from serum levels of inhaled steroids about the concentrations in the target organ. The present investigation gives more useful information than pharmacokinetic studies analysing serum levels only, because drug concentrations in the lung became directly available. The study design allowed the time course of drug concentrations to be described by combining single data from a sufficiently high number of patients.

Human in vivo data for the tissue-serum distribution of inhaled glucocorticoids and drug deposition in central and peripheral lung has not previously been investigated. Only the distribution of a glucocorticoid between the peripheral lung tissue and plasma of patients was studied after inhalation of $1.6 \mathrm{mg}$ budesonide [9].

The higher FP concentrations in central lung tissue compared with peripheral lung tissue is not unexpected, since deposition of an inhaled drug is likely to decrease with greater distance from the trachea. This may also explain differences in drug deposition found in central lung tissue between patients where tissue samples were obtained from bronchi of different diameter. No close correlation was found for FP concentrations in the central airways and FEV1, vital capacity or the presence of mucus. However, in two of the three patients having viscous mucus in the upper airways, we found high FP concentrations of about $20 \mathrm{ng} \cdot \mathrm{g}^{-1}$, and another patient with $22 \mathrm{ng} \cdot \mathrm{g}^{-1} \mathrm{FP}$ in central lung tissue presented the lowest FEV1.

Systematic investigations of drug deposition and distribution to tissue in the central airways are needed, to obtain a better understanding of drug deposition as a function of the distance from the trachea as well as a function of airway diameter. The higher FP concentrations in central lung tissue persisted for more than 17 $\mathrm{h}$, in contrast to the steadily declining concentrations in peripheral lung tissue. There are two probable reasons for this difference. Firstly, FP particles deposited in central lung tissue are likely to be of bigger mean size than those deposited in peripheral lung tissue. Secondly, the density of blood capillaries is higher in peripheral than in central tissue, so that the tissue-plasma exchange rate is higher in peripheral tissue and FP tissue concentrations decrease faster.

The lung tissue concentration of FP found in this study is estimated to be approximately 10-100 times higher than the concentration of FP previously calculated to occupy $50 \%$ of human glucocorticoid receptor in vitro [4]. This means that the tissue receptor binding sites should be $100 \%$ saturated with FP, still leaving a non(receptor)-bound excess. Thus, FP can exhibit its antiinflammatory action over a longer period of time, since 
it is stored in lung tissue for a prolonged period in sufficiently high concentrations. The prolonged presence of FP in lung tissue, together with the high relative receptor affinity to the glucocorticoid receptor, helps to explain the high clinical efficacy of FP.

Under steady-state conditions it is to be expected that FP concentrations in lung tissue and plasma are higher than in the present study after a single dose, because plasma concentrations of FP under steady-state conditions are about $50 \%$ higher compared to single dosing [10].

In the present study, the FP concentrations in peripheral lung tissue following inhalation of a $1.0 \mathrm{mg}$ dose were twice as high as those found for budesonide in a similar study [9]. Whereas linear regression analysis showed a statistically significant correlation between FP concentration and time in peripheral lung tissue $(\mathrm{r}=0.74$; $\mathrm{p}>0.001$ ), a significant correlation was not demonstrable with budesonide concentrations in lung parenchyma $(\mathrm{r}=0.37 ; \mathrm{p}=\mathrm{NS})$. This might be due to high variation of data, or to the fact that lung tissue and serum concentrations were measured up to $4 \mathrm{~h}$ only. In contrast to tissue concentrations, vAN DEN BOSCH et al. [9] found that budesonide concentrations in plasma were considerably higher than FP serum concentrations.

The results of the present study and of the study with budesonide [9] confirm our in vitro data with human lung tissue [5-7]. After saturation of human lung tissue in vitro with glucocorticoids and subsequent incubation in serum, the total concentration of FP remaining in the human lung tissue was about three times higher than for budesonide after $1 \mathrm{~h}$ in vitro, whereas FP concentrations in vivo were twice as high as for budesonide.

The parallel decline of FP concentrations in peripheral lung tissue and serum indicates that the delivery of FP from tissue to serum is the rate-limiting step for the elimination of FP.

Whereas the correlation of in vitro with in vivo data was high if the study was performed with human lung tissue [5-7], in vitro data obtained with rat tissue [10] did not correspond with the results of this FP in vivo study or with the budesonide in vivo study [9], since MilLer-LaRsson et al. [11] found that $40-50 \%$ of budesonide and only $30-40 \%$ of FP was left in the trachea in vitro $2 \mathrm{~h}$ after administration of the glucocorticoid.

The preclinical results that we obtained with fluticasone propionate, such as its affinity to the human glucocorticoid receptor [3], the receptor kinetics [4], and the binding to and retention in human lung tissue in vitro [5-7] concurrently proved that fluticasone propionate is a long-acting and very potent glucocorticoid. The in vivo study presented here is in good accordance with these previous findings.

\section{References}

1. Ryrfeldt Å, Andersson P, Edsbacker S, Tonnesson M, Davies D, Pauwels R. Pharmacokinetics and metabolism of budesonide, a selective glucocorticoid. Eur $J$ Respir Dis 1982; 63 (Suppl. 122): 86-95.

2. Pauwels R. Use of corticosteroids in asthma. In: D'Arcy PF, McElnay JL, eds. Pharmacy and Pharmacotherapy of Asthma. Chichester, Ellis Harwood, 1989; pp. 104-118.

3. Würthwein G, Rehder S, Rohdewald P. Lipophilicity and receptor affinity of glucocorticoids. Pharm Zgt Wiss 1992; 137: 161-167.

4. Högger P, Rohdewald P. Binding kinetics of fluticasone propionate to the human glucocorticoid receptor. Steroids 1994; 59: 597-602.

5. Högger P, Bonsmann U, Rohdewald P. Distribution and intrinsic activity of inhaled glucocorticoids in vitro. Eur J Pharm Sci 1994; 2: 159.

6. Högger P, Bonsmann U, Rohdewald P. Efflux of glucocorticoids from human lung tissue to human plasma in vitro. Eur Respir J 1994; 7 (Suppl. 18): 382s.

7. Rohdewald P, Bonsmann U, Högger P. Die Bindung inhalativer Glukokortikoide an menschliches Lungengewebe in vitro. In: Leupold $\mathrm{W}$, Nolte $\mathrm{D}$, eds. Neue Aspekte der Inhalativen Glukokortikoid-Therapie des Asthma Bronchiale. München-Deisenhofen, Dustri-Verlag Dr. K. Feistle. 1995; pp. 14-27.

8. Bain BM, Harrison G, Jenkins KD, Pateman AJ, Shenoy EVB. A sensitive radioimmunoassay, incorporating solidphase extraction, for fluticasone-17-propionate in plasma. J Pharm Biomed Anal 1993; 11: 557-561.

9. Van den Bosch JMM, Westermann CJJ, Aumann J, Edsbäcker S, Tönnisson M, Selroos O. Relationship between lung tissue and blood plasma concentrations of inhaled budesonide. Biopharm Drug Disp 1993; 14: 455459.

10. Thorsson L, Källén A, Wirén J-E, Paulson J. Pharmacokinetics of inhaled fluticasone propionate. Eur Respir J 1996; (Suppl. 23): 1645.

11. Miller-Larsson A, Mattsson H, Ohlsson S, et al. Prolonged release from the airway tissue of glucocorticoids budesonide and fluticasone propionate as compared to beclomethasone dipropionate and hydrocortisone. Am J Respir Med 1994; 149: A466. 